\title{
Divergence in energy sources for Prochilodus lineatus (Characiformes: Prochilodontidae) in Neotropical floodplains
}

\author{
Evanilde Benedito ${ }^{1}$, Ana Rute A. Santana ${ }^{2}$ and Martin Werth ${ }^{3}$
}

The stable carbon isotopic variability and the contributions of autochthonous (sediment microbial biomass, phytoplankton, and periphyton) and allochthonous (soil microbial biomass) sources available to the detritivorous fish Prochilodus lineatus were investigated in three environments of the floodplain of the Upper Paraná River. The isotopic composition of carbon sources and fish varied significantly among the studied environments. The autochthonous resources, represented by the phytoplankton, were the most assimilated by the species, followed by periphyton and sediment microbial biomass. The species used the sources differently in each environment. This study suggests that the inherent characteristics of this area, as well as the size of the watershed, the dry season, anthropogenic actions, and phytoplankton productivity, favor the use of autochthonous resources by the species studied. Therefore, studies in the floodplain should employ an eco-hydrological approach that quantifies the magnitude of energy subsidies, as well as an access route to consumers, knowledge about the selectivity of detritivorous species and the effects of different land uses.

Keywords: Aquatic ecosystems, Carbon sources, Fish, Organic matter, Stable isotopes.

A variabilidade isotópica e as contribuições autóctones (biomassa microbiana do sedimento, fitoplâncton e perifíton) e alóctone (biomassa microbiana do solo) assim como as principais fontes de carbono para o peixe detritívoro Prochilodus lineatus foram investigadas em três diferentes ambientes, da planície de inundação do alto rio Paraná. A composição isotópica das fontes de carbono e dos consumidores variaram significativamente entre os ambientes estudados, e os recursos alóctones, representados pelo fitoplâncton, foram os mais utilizados pela espécie, seguido pelo perifíton e biomassa do sedimento microbiano. A espécie utilizou fontes de carbono distintas em cada ambiente. Este estudo sugere que características inerentes a cada ambiente, assim como o tamanho do ambiente, o período de seca, ações antropogênicas e produtividade do fitoplâncton favorecem o uso dos recursos alóctones pela espécie estudada. Portanto, estudos na planície de inundação devem empregar uma abordagem eco-hidrológicas que quantifique a magnitude dos subsídios energéticos, bem como as vias energéticas aos consumidores, o conhecimento acerca da seletividade das espécies de detritívoros e o efeito dos diferentes usos da terra.

Palavras-chave: Ecossistemas aquáticos, Fontes de carbono, Isótopos estáveis, Matéria orgânica, Peixes.

\section{Introduction}

Freshwater aquatic food chains are maintained by autochthonous sources of detritus, derived from phytoplankton, periphyton, sediment, macrophytes, and microorganisms, as well as by allochthonous sources (i.e., material originating from terrestrial vegetation) (Cole et al., 2011). Historically, it has been assumed that autochthonous carbon is responsible for the maintenance of aquatic consumers, especially carbon derived from the phytoplankton. However, the allochthonous subsidies may also be relevant as sources of energy for food chains (Reynolds, 2008; Kon et al., 2012; Fuentes et al., 2013; Oliveira et al., 2014; Gar- cia et al., 2017). Studies on feeding interactions have also reported the relevance of bacteria due to their importance in the transformation of matter and energy (Torsvik et al., 1996), being responsible for much of the energy flow in ecosystems (Wagener et al., 1998). Odum (1988) comments that dead organic matter is transferred to microorganisms and these (again) are consumed by detritivores and predators.

Thus, due to constant interaction between aquatic and terrestrial systems, these resources are essential in floodplains (Winemiller et al., 2010). Many fish species of wetland areas have adaptive features that facilitate the exploitation of resources during seasonal flood pulses, allowing

${ }^{1}$ Núcleo de Pesquisas em Limnologia, Ictiologia e Aquicultura, PEA/PGB, Universidade Estadual de Maringá, Av. Colombo, 5790, 87020-900 Maringá, PR, Brazil. eva@nupelia.uem.br

${ }^{2}$ Programa de Pós-graduação em Educação para a Ciência e o Ensino de Matemática, Universidade Estadual de Maringá, Av. Colombo, 5790, 87020-900 Maringá, PR, Brazil. anarutesantana@yahoo.com.br D https://orcid.org/0000-0001-7084-5306 (corresponding author). ${ }^{3}$ Institute of Systematic Botany und Ecology, University of Ulm, D-89069, Ulm, Germany. martin.werth@uni-ulm.de 
the use of these areas for reproduction, refuge, and feeding (Bisson et al., 2009). These evolutionary adaptations are influenced by season and are reflected in the feeding and diet of fish species (Berra, 2007). Bozza, Hahn (2010) have reported changes in the diet and frequency of feeding in fish, caused by alterations in resources during periods of flooding in Upper Paraná River. Stephens, Krebs (1986) reported that fish optimize their nutrient acquisition, which influences the availability of food in the food choice by the consumer.

Detritivores consume a mixture of an amorphous material composed of terrestrial detritus, microorganisms, phytoplankton and periphyton (Smoot, Findlay, 2010a, 2010b), therefore playing a key role in the organization and maintenance of aquatic ecosystems (Hamilton et al., 2004). In this case, the use of stable isotopes $\left(\delta^{13} \mathrm{C}\right)$ has been shown to be appropriate because it successfully identified the origin of energy for consumers. Some studies carried out in tropical environments have proposed that most of the energy comes from the allochthonous material because the forested area has considerable supplies of tree litter and riparian vegetation. In this case, autochthonous production is limited by shading, so that the detritivorous species depend predominantly on allochthonous energy sources (Benedito-Cecilio, Araujo-Lima, 2002; Ock, Takemon, 2013). However, this is not a consensus opinion. Several authors argue that the autochthonous resources, especially those from phytoplankton and periphyton communities, are also important to detritivores. These results were reported in several regions, including small shaded streams in Porto Rico (March, Pringle, 2003), Brazil (Brito et al., 2006), and for tropical Asia (Mantel et al., 2004), in arid regions (Bunn et al., 2006), Australia (Medeiros, Arthington, 2011), the Orinoco (Lewis et al., 2001), and in the floodplain of the Amazon River (Araujo-Lima et al., 1986). Detritivorous species can use autochthonous resources as a source of energy. These species play a fundamental role in floodplains because a major part of the metabolic processes is supported by terrestrial detritus, which accounts for maintaining the detritivorous food chain (Santana et al., 2015).

Among detritivorous species, the migratory Prochilodus lineatus (Valenciennes, 1836), commonly known as curimba, is a fish of commercial interest and consumes inorganic sediment, organic detritus, microinvertebrates, and algae (Fugi et al., 1996), and occurs in all environments of the floodplain of the Upper Paraná River in Brazil (LoweMcConnell, 1999).

Using $\delta^{13} \mathrm{C}$ stable-carbon isotope ratios, this study investigates the contribution of autochthonous resources, including as the main sources: phytoplankton, periphyton and microbial biomass of organic matter in the sediment. Furthermore, the microbial biomass of terrestrial soil organic matter was considered as an allochthonous source of nutrition. This work was conducted under the hypothesis that the carbon source used by detritivorous fish, $P$. lineatus, comes from autochthonous resources.

\section{Material and Methods}

Study area. The floodplain of the Upper Paraná River is located in South of Brazil, on the border of the states, Paraná and Mato Grosso do Sul $\left(22^{\circ} 45^{\prime} \mathrm{S}, 53^{\circ} 30^{\prime} \mathrm{W}\right)$ (Fig. 1). This study was conducted in the Paraná, Baía, and Ivinheima Rivers form this floodplain area. The Paraná River varies widely in depth, with an average of $4 \mathrm{~m}$ but can exceed 15 $\mathrm{m}$ during the wet period; the vegetation consists of sparse trees and grasses. The average depth of the Baía River is $3.2 \pm 4.26 \mathrm{~m}$, with riparian vegetation and fields affected by human activities (agriculture and cattle-raising activities), as well as fields of floodplains, aquatic macrophytes, and grasses. The Ivinheima River has an average depth of 3.9 $\mathrm{m}$ and variation of $2.94 \mathrm{~m}$, with quite diverse vegetation, including herbaceous, grass, wetland and riparian species at different stages of regeneration. This environment presents significant, differentiated and complex characteristics. The hydrological regime is bimodal, with floods from December to March and August to September that reach a depth of up to $4.0 \mathrm{~m}$ (Souza-Filho et al., 2004).

Sampling design. The sampling was conducted in July 2010 (dry season) in the floodplain of the Upper Paraná River in three environments: Paraná, Baía, and Ivinheima (Fig. 2). In this period, the connectivity between environments from floodplain is lower than in other periods. In Paraná and Baía rivers, two sites were sampled each, whereas three sites were sampled $n$ Ivinheima River. Unfortunately, the next period of wet has an elevated hydrometric level (Fig. 2), and the points in the majority of environments were submerged and could not be sampled.

The primary sources of energy considered were: phytoplankton and periphyton. The phytoplankton samples were obtained with plankton nets of $15 \mu \mathrm{m}$ (without zooplankton) and the periphyton by scraping stems of aquatic plants, being composed of five samples of phytoplankton and five samples of periphyton in each environment studied. Samples were retained on glass fiber filters (previously undergone combustion at $550^{\circ} \mathrm{C}$ for $4 \mathrm{~h}$ ).

The abiotic data, soil samples (allochthonous), and sediment samples (autochthonous) were taken at three points in each transect in every environment. For the soil samples, a core sampler (5-cm diameter and 0-10 $\mathrm{cm}$ depth) was used. For the sediment, samples were collected at $0-5 \mathrm{~cm}$ in depth, with the aid of a simplified collector type core sampler for sediment (Boyd, 1995) to avoid the influence of the water column. The sampling of soil and sediment was carried out in a transect composed of four soil samples and three sediment samples. The transects were conducted from the right margin until the left margin, and the samples had $2 \mathrm{~m}$ of distance between them. In larger lagoons (Ivinheima River), five sediment samples were collected. The soil samples were collected close to the banks of the lagoons, with a distance of approximately $2 \mathrm{~m}$ between the points. In the case of the sediment transect, the samples were taken near the edges and 


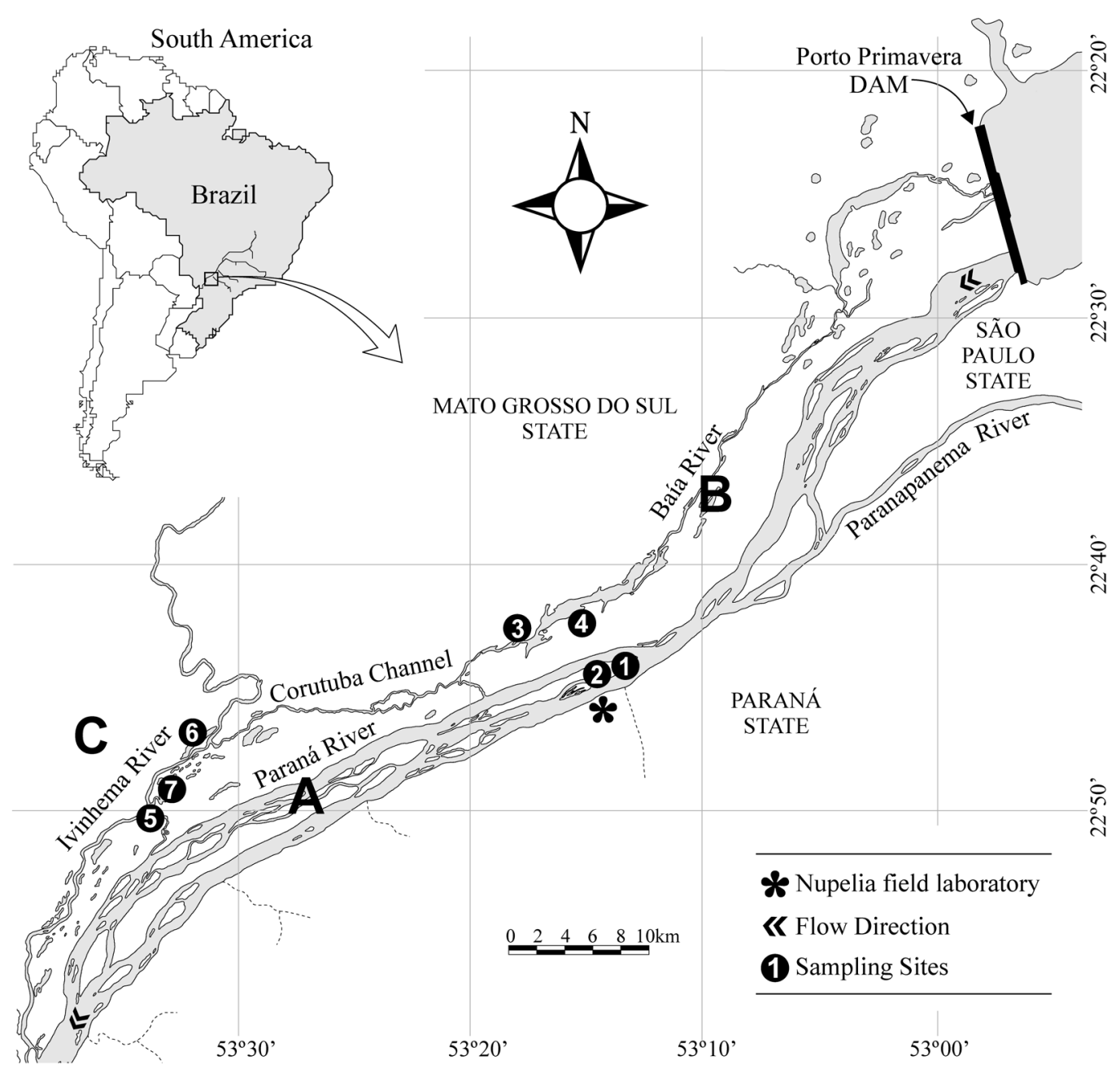

Fig. 1. Map of the floodplain of the Upper Paraná River, highlighting the areas sampled in this study. The subsystems sampled were $\mathrm{A}=$ Paraná River, $\mathrm{B}=$ Baía River and $\mathrm{C}=$ Ivinheima River. The numbers indicate sampled sites in each subsystem.

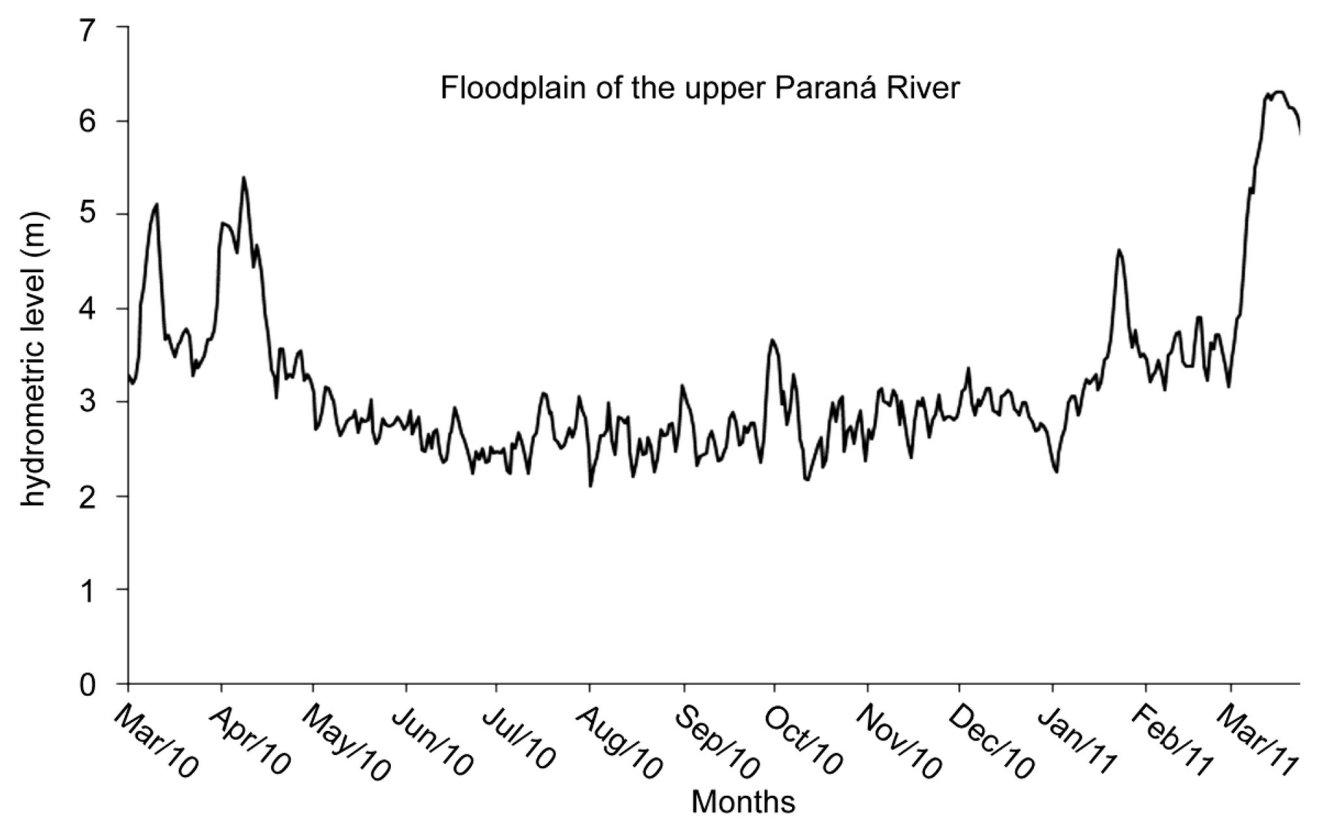

Fig. 2. Hydrometric level from dry and wet periods in the floodplain of the Upper Paraná River. 
center of the lagoons. For the larger lagoons, one sample of each sediment was collected close to either margin and three samples additional samples were collected along the transect in the lagoon at approximately similar distances.

The specimens of $P$. lineatus were sampled using gill nets; five fish were collected in each environment studied (Paraná, Baía and Ivinheima rivers). Prochilodus lineatus is a migratory fish, and the environments are relatively close. However, the detritivorous feed continuously due to low nutritive values of the diet (Yossa, Araujo-Lima, 1998) and for this reason the isotopic values are significantly different among environments from the floodplain of the Upper Paraná River (Lopes et al., 2007). Some of the collected specimens of $P$. lineatus were deposited in the Ichthyology Collection of NUPELIA (Núcleo de Pesquisas em Limnologia, Ictiologia e Aquicultura, Universidade Estadual de Maringá, Paraná State) (NUP 11092 - http://peixe.nupelia. uem.br/). All adult specimens had a similar standard length (Ls, cm) and total weight (Wt, g), which were determined before a small portion of muscle (located at the base of the dorsal fin) was removed. The muscle samples were dried at $60^{\circ} \mathrm{C}$ for 36 to $48 \mathrm{~h}$, and ground until obtaining a fine and homogeneous powder, of which approximately $0.001 \mathrm{~g}$ was weighed into tin capsules for mass spectrometry.

In the Energy Ecology Laboratory at the State University of Maringá, the samples were submitted to a fumigationextraction method with chloroform according to Vance et al., (1987). The extracts were frozen until sent for analysis of total organic carbon concentration (in Analytical Model 1030 TOC Analyzer, Sercon Ltd., Cheshire, UK) and $\delta^{13} \mathrm{C}$ in (PDZ Europa ANCA-GSL Mass Spectrometer, Sercon Ltd., Cheshire, UK).

Data Analysis. The values of the isotope ratios were expressed in delta notation $(\delta)$ and in parts per thousand (\%o) (Bond, Hobson, 2012) relative to the international standard Viena Pee Dee Belemnite (VPDB). All biological material prepared was sent to the UC Davis Stable Isotope Facility, USA, for analysis of $\delta^{13} \mathrm{C}(\%)$ in the isotope ratio mass spectrometer (PDZ Europa ANCA-GSL, Sercon Ltd., Cheshire, $\mathrm{UK})$, according to the expression:

$$
\delta^{13} \mathrm{C}=\left[\left(\mathrm{R}_{\text {sample }} / \mathrm{R}_{\text {standard }}\right)-1\right] \times 10^{3}
$$

where: $\mathrm{R}=$ carbon isotope ratios $={ }^{13} \mathrm{C} /{ }^{12} \mathrm{C}$

For the microbial biomass carbon $(\mathrm{C})$ an extraction coefficient $\left(\mathrm{K}_{\mathrm{EC}}\right)$ of 0.45 was used (Wu et al., 1990). To determine the microbial biomass $\delta^{13} \mathrm{C}\left(\delta^{13} \mathrm{C}_{\mathrm{MB}}\right)$, a mass balance was calculated according to the equation (Werth, Kuzyakov, 2008):

$$
\delta^{13} C_{\text {MB }}=\left(\delta^{13} C_{\text {fum }} \times C_{\text {fum }}-\delta^{13} C_{\text {nfum }} \times C_{\text {nfum }}\right) / C_{\text {fum }}-C_{\text {nfum }}
$$

where, $\delta^{13} \mathrm{C}_{\text {fum }}$ and $\mathrm{C}_{\text {fum }}$ are measured in chloroform-fumigated samples, and $\delta^{13} \mathrm{C}_{\text {nfum }}$ and $\mathrm{C}_{\text {nfum }}$ are obtained from samples that were not treated with chloroform (Murage, Voroney, 2007) and the correction factor was 2,22 the total carbon in ppm.
For graphical and statistical analysis, parametric and nonparametric tests were performed with the Statistica program (version 7.0 - StatSoft). One-way ANOVA with the Tukey HSD post hoc test was used to compare the differences of means among the isotopic sources of carbon and environments studied. In cases where the assumptions of normality and homoscedasticity were not fulfilled, the Kruskal-Wallis test was used. A 5\% level of significance was considered for both tests.

The contribution of energy sources for $P$. lineatus was calculated by the IsoSource program (Phillips, Gregg, 2003). Only $\delta^{13} \mathrm{C}$ values were available. Isosource model is helpful at inferring possible diet compositions when a unique solution cannot be calculated (Hopkins, Ferguson, 2012) once uses rules of mass balance to examine all possible source combinations that could result in observed isotope value, and provides range of possible proportional contributions (Layman et al., 2012). Although IsoSource does not include sampling and measurement sources of uncertainty in a straightforward way (Phillips et al., 2014). For the calculations of carbon sources contributions an isotopic discrimination of $1 \%$ was considered, the tolerance values used were 0.1 for the Paraná and Baía rivers and 0.05 for Ivinheima, and the increment used was $1 \%$ in all cases. Tolerance values can range from 0.05 to 0.2 (Phillips, Greg, 2003). Stable isotope missing model presented feasible solutions when performed with small tolerances, in which the frequency and reach of the potential contributions of the source could be determined.

\section{Results}

Isotopic values. Isotope ratios for $\delta^{13} \mathrm{C}$ from consumers and resources were higher in the Paraná (between -28\%o and $-19 \%$ ) and lower for Baía and Ivinheima rivers (between $-32 \%$ and $-26 \%$ ) than other floodplain environments the Upper Paraná River (Fig. 3). The $\delta^{13} \mathrm{C}$ values of detritivorous $P$. lineatus differed significantly among the rivers $(\mathrm{p}=0.01)($ Tab. 1$)$.

Tab. 1. Mean values and standard deviations of abiotic parameters from the Paraná, Baía and Ivinheima subsystems in dry season.

\begin{tabular}{lccc}
\hline \multirow{2}{*}{ Abiotic data } & \multicolumn{3}{c}{ Subsystems } \\
\cline { 2 - 4 } \multicolumn{1}{c}{ Paraná } & Baía & Ivinheima \\
\hline Oxygen $\left(\mathrm{mg} \mathrm{l}^{-1}\right)$ & $8.2 \pm 1.03$ & $8.7 \pm 0.53$ & $8.9 \pm 1.04$ \\
Water temperature $\left({ }^{\circ} \mathrm{C}\right)$ & $20.3 \pm 0.33$ & $22.8 \pm 0.74$ & $17.9 \pm 0.25$ \\
$\mathrm{pH}$ & $7.4 \pm 0.20$ & $6.8 \pm 0.17$ & $7.7 \pm 0.80$ \\
Conductivity $\left(\mu \mathrm{S} \mathrm{cm}^{-1}\right)$ & $65.0 \pm 0.54$ & $29.5 \pm 0.87$ & $43.3 \pm 3.07$ \\
\hline
\end{tabular}

Contribution of carbon sources. We found that $P$. $l i$ neatus consumed different sources in each environment studied. In the Baía environment, the fish principally used periphyton $(77 \%)$, followed by phytoplankton (11\%). In the Paraná environment, the fish principally assimilated phytoplankton $(75 \%)$, followed by periphyton $(18 \%)$, whereas in 

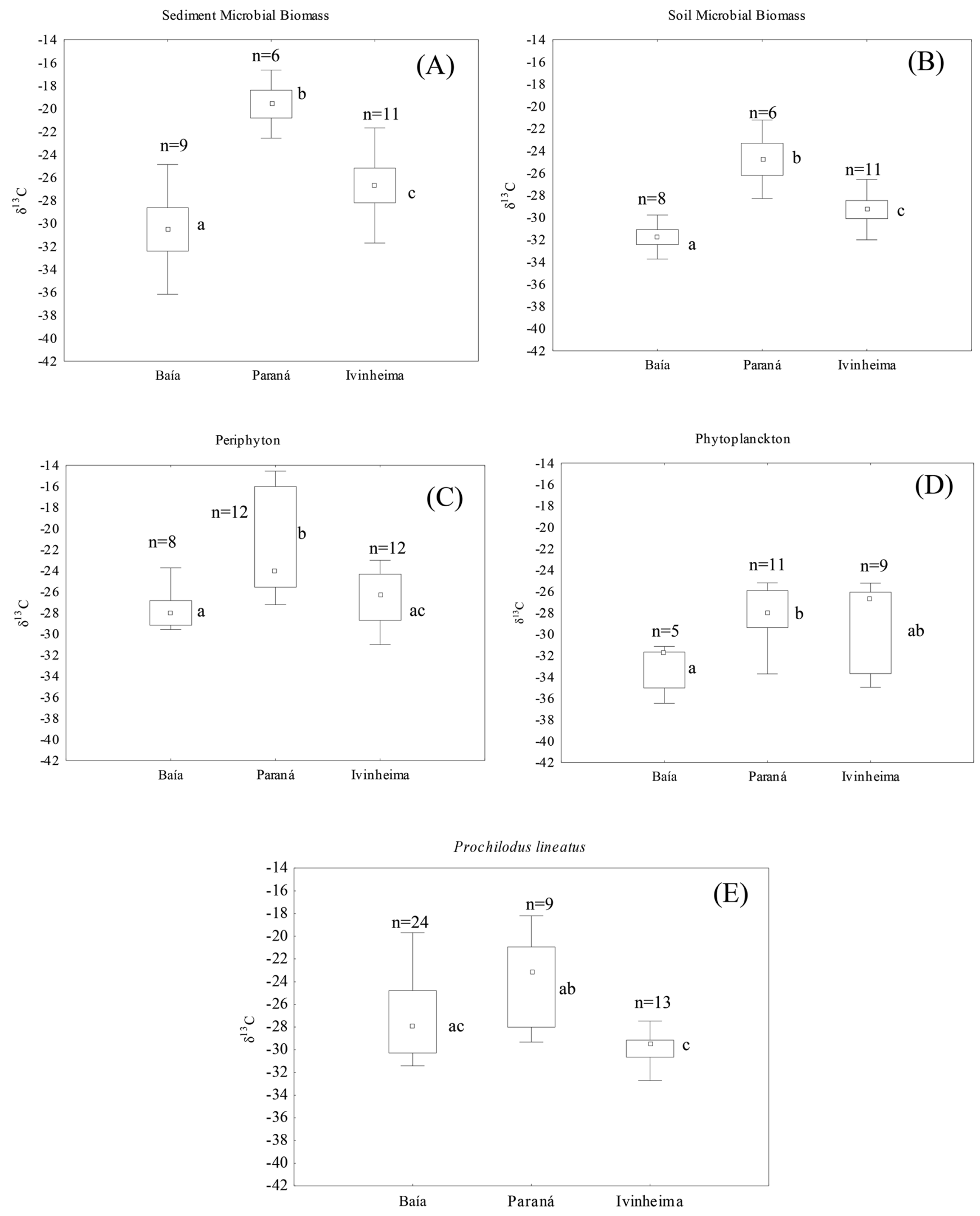

Fig. 3. $\delta 13 \mathrm{C}$ values of food sources (A to D) and of P. lineatus (E). The box-whisker-plots show the lower and upper quartile $(25 \%-75 \%)$, median ( $\square)$, minimum and maximum (vertical bars). The small letters represent significant differences between the components studied in Paraná, Baía and Ivinheima subsystems of the floodplain of the Upper Paraná River $(\mathrm{n}=$ number of samples). 
Ivinheima the species principally assimilated MB sediment (51\%) and MB soil (25\%) (Tabs. 2-3 and Fig. 4). The algae presented an average contribution higher than $88 \%$ in the environments of Paraná and Baía River, and in contrast, it was lower than $21 \%$ in Ivinheima.

Tab. 2. The values of results of ANOVA and Kruskal-Wallis tests from carbon sources for P. lineatus in the area studied (MB: Microbial Biomass).

\begin{tabular}{lccllcc}
\hline & \multicolumn{2}{c}{ ANOVA } & & \multicolumn{3}{c}{ Kruskall-Wallis } \\
\cline { 2 - 3 } \cline { 5 - 6 } & $\mathrm{F}$ & $\mathrm{p}$ & & $\mathrm{H}$ & $\mathrm{p}$ \\
\hline MB sediment & 8.99 & 0.0010 & & Periphyton & 10.25 & 0.005 \\
\multirow{2}{*}{ MB soil } & 12.15 & 0.0002 & & Phytoplankton & 4.90 & 0.080 \\
& & & & P. lineatus & 9.12 & 0.01 \\
\hline
\end{tabular}

Tab. 3. Contributions of carbon sources to nutrition of $P$. lineatus. Variations in the contribution of the resources are presented in 1-99 (50) percentile and standard deviation (SD) for the consumer in each subsystem studied in the floodplain of the Upper Paraná River. The values in parentheses indicate the median ( $\mathrm{MB}=$ Microbial Biomass).

\begin{tabular}{lcccc}
\hline \multirow{2}{*}{ Subsystem } & \multicolumn{4}{c}{ Sources (\%) } \\
\cline { 2 - 5 } & MB sediment & MB soil & Periphyton & Phytoplankton \\
\hline Baía & $0-20(6)$ & $0-14(4)$ & $63-86(77)$ & $0-35(11)$ \\
Paraná & $0-9(3)$ & $0-8(3)$ & $1-34(18)$ & $62-88(75)$ \\
Ivinheima & $1-72(51)$ & $0-64(25)$ & $0-1(1)$ & $0-94(20)$ \\
\hline
\end{tabular}

\section{Discussion}

Floodplains are environments with heterogeneous landscapes associated with mosaics of food webs (Bellmore et al., 2013), reinforcing the paradigm that these areas are biophysically complex "hotspots" (Junk et al., 1989; Stanford et al., 2005). Thus, they may also be considered "hotspots" with complex feeding interactions (Bellmore et al., 2013).

In this study, we identified considerable variability in isotopic signatures from carbon sources in different environments, but also in contributing to the energy sources of detritivorous $P$. lineatus. Studies in flooded areas have emphasized the relationship between the structure of fish assemblages and the pathways of organic matter. The flood pulses redistribute organic material, providing interaction between the aquatic and terrestrial environment (Junk et al., 1989; Stanford et al., 2005). This fact may have influenced the isotopic variability observed for the carbon sources and the consumer both in different environments.

In relation to microbial sources, derived from the autochthonous and allochthonous organic matter, isotopic variation can be related to the carbon assimilated by microorganisms in various environments (Pelz et al., 1998), taking into account the basic principle of studies with stable isotopes that the organisms isotopically represent their source of energy (DeNiro, Epstein, 1978).

The floodplain of the Upper Paraná River has high plant diversity associated with forest and shrubby formations (Ro- magnolo, Souza, 2000), which shows the predominance of species with the $\mathrm{C}_{3}$ photosynthetic pathway. These plants exhibit $\boldsymbol{\delta}^{13} \mathrm{C}$ values between $-32.0 \%$ and $-22.0 \%$ (Boutton et al., 1998). These characteristics may justify the isotopic value of the allochthonous microbial biomass, which is quite similar to the isotopic signature of vegetation, a result also evidenced by Lopes et al. (2007). These authors analyzed other available resources for $P$. lineatus, including phytoplankton and periphyton, which showed similar isotopic values. Thus, although the nutritional variation for detritivorous fish in Neotropical floodplains may be diversified, several studies about food sources have reported the importance of phytoplankton, especially in the dry season (Araujo-Lima et al., 1986; Lopes et al., 2007).

The source of greatest contribution to P. lineatus originated from the autochthonous material. Large contributions of phytoplankton were found in Paraná River, periphyton in Baía and the microbial biomass in the Ivinheima River. The higher contribution from autochthonus sources may be a reflex of the dry season and this result may not be repeated during the flood pulses. On the other hand, the origin of allochthonous resources is essential since many consumers use terrestrial organic carbon as a food resource. Outstanding among these consumers are microorganisms (Berggren et al., 2010), zooplankton (Cole et al., 2011), benthic invertebrates (Solomon et al., 2008), and fish (Medeiros, Arthington, 2011; Solomon et al., 2011). However, in contrast, other studies have suggested that the terrestrial organic matter contributes little to the nutrition of aquatic consumers (Brett et al., 2009).

In this context, former studies on stable carbon isotopes in the fish species Dorosoma cepedianum (Lesueur, 1818) have to be considered, because like $P$. lineatus, this species also has morphological adaptations to consume detritus from sediment and phytoplankton (Pilati, 2007; Zeug, Winemiller, 2008; Smoot, Findlay 2010a, 2010b). In these studies, D. cepedianum assimilated carbon from both allochthonous and autochthonous origin in floodplains. This result was related to hydrology, since according to Wetzel (1990) the proportion of terrestrial inputs is higher on wetlands than rivers, whereas autochthonous production is higher in rivers than wetlands. Another study investigating the isotopic ratios for the same fish species indicated that, although they are dependent on carbon sources from both origins, autochthonous items prevailed, with phytoplankton contributing more than $50 \%$ to the production of fish biomass throughout the environments studied (Babler et al., 2011).

Other authors have aimed to explain these results and reported that the consumer prefers items with high carbon and nutrient contents (Higgins et al., 2006). Thus, detritivores have high selectivity, ingesting sediment particles enriched in organic matter, which include detritus of terrestrial plants, algae, and microorganisms (Smott, Findlay, 2010a). Smott, Findlay (2010a, 2010b) also mention that allochthonous organic carbon may contribute indirectly to the detritus biomass, by the fact that autochthonous microorganisms utilized terrestrial detritus as a resource. 


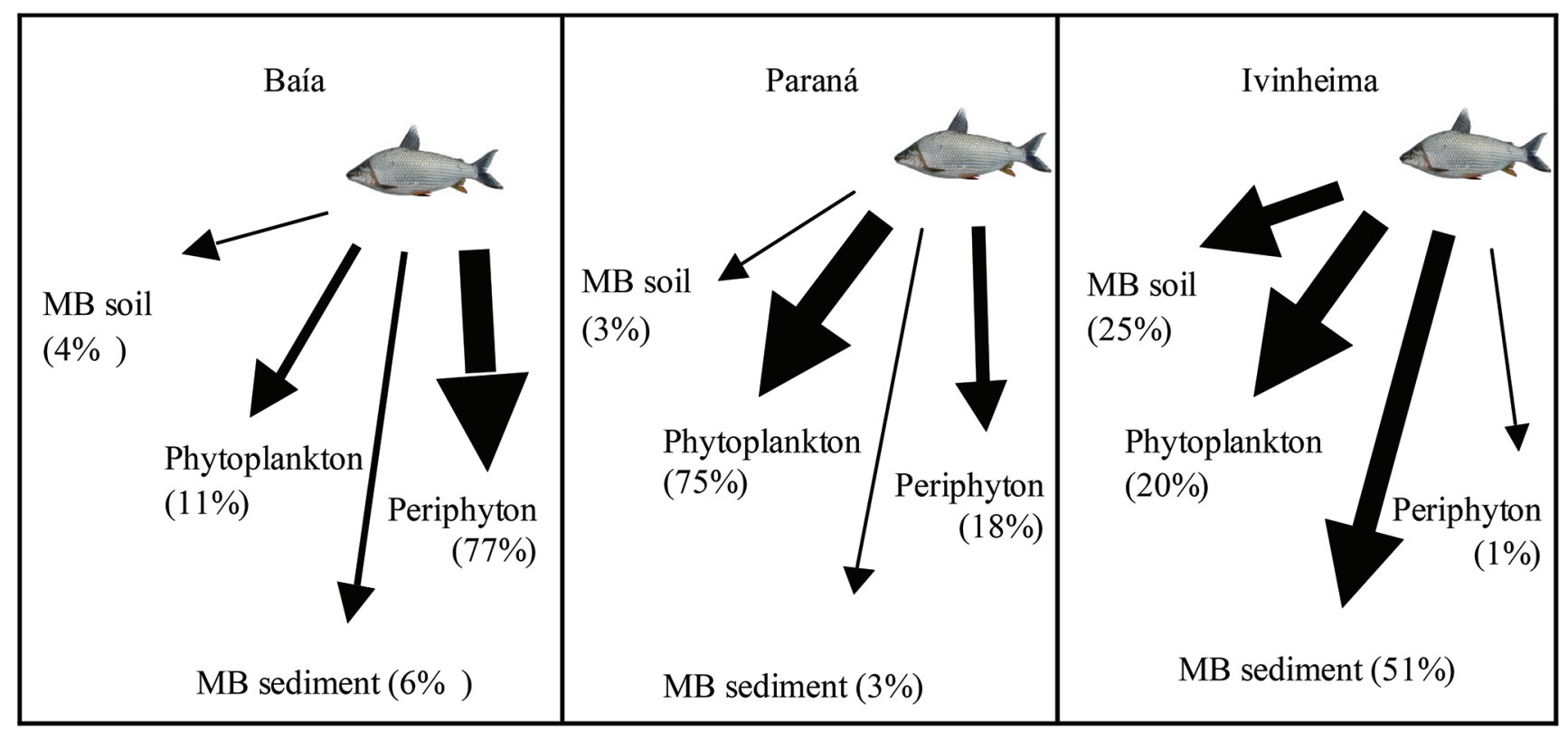

Fig. 4. The average percentage contribution of each carbon source in different subsystems. The width of arrows represents the strength of resource utilization in each environment studied $(\mathrm{MB}=$ microbial biomass).

In an experiment in mesocosms, Pilati (2007) added carbon derived from Zea mays L. (maize) to the sediment and found (by this natural ${ }^{13} \mathrm{C}$ labeling approach), that the terrestrial carbon was assimilated. It was unclear if the carbon was incorporated directly, or by a pathway of microorganisms that also utilized the detritus coming from maize. This trend was also registered in this study, primarily in the Ivinheima River, where the use of microbial biomass by P. lineatus was predominant. Hence, it is possible that the species had assimilated carbon derived from terrestrial sources via the microorganisms pathway. The nutrients and other terrestrial materials originating from agricultural areas may increase phytoplankton production, consequently providing a high amount of phytodetritus for detritivorous fish, explaining the use of autochthonous sources in several studies (Bremigan et al., 2008). It is worth mentioning that the environments of the floodplain of the Upper Paraná River suffer from negative agricultural effects (Agostinho et al., 2004), which might have caused the greater assimilation of autochthonous carbon by P. lineatus.

The studies mentioned above show the importance of allochthonous and autochthonous resources for bottom foraging fish species. The phytoplankton was the main resource used by the species. Isotopic studies have shown the significant contribution of phytoplankton algae to aquatic organisms, including detritivorous fish (Araujo-Lima et al., 1986; Benedito-Cecilio et al., 2000; Benedito-Cecilio et al., 2004; Lopes et al., 2015) and zooplankton (Santana et al., 2009 ; 2011). Among these are studies on the Orinoco River (Venezuela and Colombia), which showed that phytoplankton was among the main carbon sources for fish and invertebrates (Lewis et al., 2001). Similarly, Araujo-Lima et al. (1986) found that detritivorous fish from the floodplain of the Amazon River used detritus derived from phytoplankton production. In the floodplain of the Upper Paraná River, the isotopic analysis of muscles of $P$. lineatus, revealed that phytoplankton algae are among the main sources of carbon used by species of fish in the studies developed by Lopes et al. (2007). This trend can also be justified by the fact that, in the period from 2000 to 2007, the phytoplankton biomass was considerably higher in the floodplain, while the highest value was registered for the Paraná River, followed by Baía and Ivinheima Rivers (Rodrigues et al., 2009). In Ivinheima the contribution from MB soil was the highest, once that this environment has the greatest ecological integrity, since its banks are more preserved (Agostinho, Zalewski, 1996).

There are many considerations about the resources used by detritivorous fish, and there are many uncertainties (Moore et al., 2004). Detritivores consume a mixture of material composed of terrestrial detritus and microorganisms (Smoot, Findlay, 2010a, 2010b). Besides the importance of phytoplankton for detritivores (Araujo-Lima et al., 1986; Benedito-Cecilio et al., 2000; Benedito-Cecilio et al., 2004; Angelini et al., 2013) other sources (riparian vegetation, particulate organic matter, periphyton, and macrophytes) are also relevant (Manetta et al., 2003; Lopes et al., 2007). Given this contrast, it is important to emphasize that both energy sources are important. However, the major challenge is to determine the factors that regulate the use of these resources by fish species. These factors may be related to the size and characteristics of the aquatic ecosystem. For example, in situations where the allochthonous production decreases with surface area, autochthonous production increases (Pace et al., 2007). Another situation occurs when large aquatic areas receive both terrestrial organic carbon and inorganic nutrients (Wetzel, 1990), often originating from agriculture. 
Such nutrients increase phytoplankton production (Vanni et al., 2011).

Considering the above, it appears that the detritivorous fish species $P$. lineatus used autochthonous resources as carbon sources. However, the importance of the wetlands was highlighted, because they have a large input of organic material (due to their inherent characteristic of seasonal floods) (Agostinho, Zalewski, 1996). The authors have reported that these environments are dynamic and with high species diversity. However, the authors highlight that the Upper Paraná River is a region that has considerable anthropogenic influence, which is reflected in the biotic community. This basin has the greatest demographic density in the country and, thus, has of large water demand. Agostinho, Zalewski (1996) point out that the water for irrigation in the intense agriculture, the livestock activities, the inadequate soil management, the pesticides used, and the degradation of riparian vegetation have harmed the quality of water for human use and aquatic life. For these authors, the largest anthropogenic impact is the dams because they have significantly modified the physiographic characteristics of this basin, affecting all principal affluents and the hydrological regime of the Paraná floodplain.

This study showed the importance of phytoplankton and periphyton as an energy source for $P$. lineatus. However, the finding that this fish species consumed these sources differently in each environment provide evidence of the importance of environmental factors for food selectivity. Therefore, studies should employ an eco-hydrological approach that quantifies the magnitude of energy subsidies, as well as assesses routes to aquatic consumers. It is also important to clarify under what conditions the input of organic matter is dependent on allochthonous or autochthonous sources, and why and how the consumers select energy resources to be assimilated. For this, it is essential to gain knowledge about the selectivity of the species, the size of the watershed, the extent of allochthonous resources, phytoplankton productivity, and different land uses. Such studies are important to trace the influence of these pathways in the carbon cycle of aquatic food chains, but also to protect and conserve aquatic species.

\section{References}

Agostinho AA, Gomes LC, Thomaz SM, Hahn NS. The Upper Paraná River and its floodplain: main characteristics and perspectives for management and conservation. In: Thomaz SM, Agostinho AA, Hahn NS, editors. The Upper Paraná River and its floodplain: physical aspects, ecology and conservation. Leinden: Backhuys Publishers; 2004. p.381-393.

Agostinho AA, Zalewski M. A planície alagável do alto rio Paraná: Importância e preservação. Maringá: EDUEM; 1996.

Angelini R, Morais RJ, Catella AC, Resende EK, Libralato S. Aquatic food webs of the oxbow lakes in the Pantanal: A new site for fisheries guaranteed by alternated control? Ecol Model. 2013; 253(1):82-96.

Araujo-Lima CARM, Forsberg BR, Victoria R, Martinelli L. Energy sources for detritivorous fishes in the Amazon. Science. 1986; 234(4781):1256-58.
Babler AL, Pilati A, Vanni MJ. Terrestrial support of detritivorous fish populations decreases with watershed size. Ecosphere. 2011; 2(7):art76. Available from: https://doi.org/10.1890/ ES11-00043.1

Bellmore JR, Baxter VC, Martens K, Connolly PJ. The floodplain food web mosaic: a study of its importance to salmon and steelhead with implications for their recovery. Ecol Appl. 2013; 23(1):189-207.

Benedito-Cecilio E, Araujo-Lima CARM. Variation in the carbon isotope composition of Semaprochilodus insignis, a detritivorous fish associated with oligotrophic and eutrophic Amazonian rivers. J Fish Biol. 2002; 60(6):1603-07.

Benedito-Cecilio E, Araujo-Lima CARM, Forsberg BR, Bittencourt MM, Martinelli LA. Carbon sources of Amazonian fisheries. Fisheries Manag Ecol. 2000; 7(4):305-15.

Benedito-Cecilio E, Dourado ECS, Lopes CA, Faria ACEA, Pinheiro RP, Bonnici P, Pereira AL, Morimoto M. Estimation of the energy of producers and consumers in the Upper Paraná River Floodplain. In: Agostinho AA, Rodrigues L, Gomes LC, Thomaz SM, Miranda LE. The Upper Paraná River Floodplain long term ecological research. Maringá: EDUEM; 2004. p. 145-149.

Berggren M, Ström L, Laudon H, Karlsson J, Jonsson A, Giesler R, Bergström AK, Janssnon M. Lake secondary production fueled by rapid transfer of low molecular weight organic carbon from terrestrial sources to aquatic consumers. Ecol Lett. 2010; 13(7):870-80.

Berra TM. Freshwater fish distribution. Chicago: Chicago Press, 2007.

Bisson PA, Dunham JB, Reeves GH. Freshwater ecosystems and resilience of Pacific salmon: habitat management based on natural variability. Ecol Soc. 2009; 14(1):45.

Bond AL, Hobson KA. Reporting stable-isotope ratios in ecology: recommended terminology, guidelines and best practices. Waterbirds. 2012; 35(2):324-31.

Boutton TW, Archer SR, Midwood AJ, Zitzer SF, Bol R. $\delta 13 \mathrm{C}$ values of soil organic carbon and their use in documenting vegetation change in a subtropical savanna ecosystem. Geoderma. 1998; 82(1-3):5-41.

Boyd CE. Bottom soils, sediment and pond aquaculture. New York: Chapman and Hall; 1995.

Bozza AN, Hahn NS. Uso de recursos alimentares por peixes imaturos e adultos de espécies piscívoras em uma planície de inundação neotropical. Biota Neotrop. 2010; 10(3):217-26.

Bremigan MT, Soranno PA, Gonzaalez MJ, Bunnell DB, Arend KK, Renwick WH, Stein RA, Vanni MJ. Hydrogeomorphic features mediate the effects of land use/cover on reservoir productivity and food webs. Limnol Oceanogr. 2008; 53(4):1420-33.

Brett MT, Kainz MJ, Taipale SJ, Seshan H. Phytoplankton, not allochthonous carbon, sustains herbivorous zooplankton production. PNAS. 2009; 106(50):21197-201.

Brito EF, Moulton TP, Souza ML, Bunn SE. Stable isotope analysis indicates microalgae as the predominant food source of fauna in a coastal forest stream, south-east Brazil. Austral Ecol. 2006; 31(5):623-33.

Bunn SE, Balcombe SR, Davies PM, Fellows CS, McKenzieSmith FJ. Aquatic productivity and food webs of desert river ecosystems. In: Kingsford RT, editor. Ecology of desert rivers. Cambridge: Cambridge University Press; 2006. p.76-99.

Cole JJ, Carpenter SR, Kitchell JF, Pace ML, Solomon CT, Weidel B. Strong evidence for terrestrial support of zooplankton in small lakes based on stable isotopes of carbon, nitrogen, and 
hydrogen. PNAS. 2011; 108(5):1975-80.

DeNiro MJ, Epstein S. Carbon isotopic evidence for different feeding patterns in two Hyrax species occupying the same habitat. Science. 1978; 201(4359):906-08.

Fuentes N, Güde H, Wessels M, Straile D. Allochthonous contribution to seasonal and spatial variability of organic matter sedimentation in a deep oligotrophic lake (Lake Constance). Limnologica. 2013; 43(2):122-30.

Fugi R, Hahn NS, Agostinho AA. Feeding styles of five species of bottom-feeding fishes of the high Paraná River. Environ Biol Fishes. 1996; 46(3):297-307.

Garcia AM, Winemiller KO, Hoeinghaus DJ, Claudino MC, Bastos R, Correa F, Huckembeck S, Vieira J, Loebmann D, Abreu P, Ducatti C. Hydrologic pulsing promotes spatial connectivity and food web subsidies in a subtropical coastal ecosystem. Mar Ecol Prog Ser. 2017; 567(1):17-28.

Hamilton SK, Tank JL, Raikow DF, Siler ER, Dorn NJ, Leonard NE. The role of instream vs allochthonous $\mathrm{N}$ in stream food webs: modeling the results of an isotope addition experiment. $\mathrm{J}$ North Am Benthol Soc. 2004; 23(3):429-48.

Higgins KA, Vanni MJ, González MJ. Detritivory and the stoichiometry of nutrient cycling by a dominant fish species in lakes of varying productivity. Oikos. 2006; 114(3):419-30.

Hopkins JB III, Ferguson JM. Estimating the diets of animals using stable isotopes and a comprehensive Bayesian mixing model. PLoS ONE. 2012; 7(1):1-13.

Junk WJ, Bayley PB, Sparks RE. The flood pulse concept in riverfloodplain systems. In: Dodge DP, editor. Proceedings of the International Large River Symposium (LARS). Can Spec Publ Fish Aquat Sci.. 1989; 106:110-27.

Kon K, Hoshino Y, Kanou K, Okazaki O, Nakayama S, Kohno H. Importance of allochthonous material in benthic macrofaunal community functioning in estuarine salt marshes. Estuarine, Coastal Shelf Sci. 2012; 96(1):236-44.

Layman CA, Araujo MS, Boucek R, Hammerschlag-Peyer CM, Harrison E, Jud ZR, Matich P, Rosenblatt AE, Vaudo JJ, Yeager LA, Post DM, Bearhop S. Applying stable isotopes to examine food-web structure: an overview of analytical tools. Biol Rev. 2012; 87(3):545-62.

Lewis WM Jr, Hamilton SK, Rodríguez MA, Saunders III JF, Lasi MA. Foodweb analysis of the Orinoco floodplain based on production estimates and stable isotope data. J North Am Benthol Soc. 2001; 20(2):241-54.

Lopes CA, Benedito-Cecilio E, Martinelli LA. Variability in the carbon isotope signature of Prochilodus lineatus (Prochilodontidae, Characiformes) a bottom-feeding fish of the Neotropical region. J Fish Biol. 2007; 70(2):1649-59.

Lopes CA, Manetta GL, Figueiredo BRS, Martinelli LA, BeneditoCecilio E. Carbon from littoral producers is the major source of energy for bottom-feeding fish in a tropical floodplain. Environ Biol Fishes. 2015; 98(4):1081-88.

Lowe-McConnell RH. Estudos ecológicos de comunidades de peixes tropicais. São Paulo: EDUSP; 1999.

Manetta GI, Benedito-Cecilio E, Martinelli LA. Carbon sources and trophic position of the main species of fishes of Baía River, Paraná River floodplain, Brazil. Braz J Biol. 2003; 63(4):283-90.

Mantel SK, Salas M, Dudgeon D. Foodweb structure in a tropical Asian forest stream. J North Am Benthol Soc. 2004; 23(4):72855.

March JG, Pringle CM. Food web structure and basal resource utilization along a tropical island stream continuum, Puerto Rico. Biotropica. 2003; 35(1):84-93.
Medeiros ESF, Arthington AH. Allochthonous and autochthonous carbon sources for fish in floodplain lagoons of an Australian dryland river. Environ Biol Fishes. 2011; 90(1):1-17.

Moore JC, Berlow EL, Coleman DC, Ruiter PC, Dong Q, Hastings A, Johnson NC, McCann KS, Melville K, Morin PJ, Nadelhoffer K, Rosemond AD, Post DM, Sabo JL, Scow KM, Vanni MJ, Wall DH. Detritus, trophic dynamics and biodiversity. Ecol Lett. 2004; 7(7):584-600.

Murage EW, Voroney PR. Modification of the original chloroform fumigation extraction technique to allow measurement of $\delta^{13} \mathrm{C}$ of soil microbial biomass carbon. Soil Biol Biochem. 2007; 39(7):1724-29.

Ock G, Takemon Y. Effect of reservoir-derived plankton released from dams on particulate organic matter composition in a tailwater river (Uji River, Japan): source partitioning using stable isotopes of carbon and nitrogen. Ecohydrol. 2013; 7(4):1172-86.

Odum EP. Ecologia. Rio de Janeiro: Guanabara; 1988.

Oliveira MCLM, Bastos RF, Claudino MC, Assumpção CM, Garcia AM. Transport of marine-derived nutrients to subtropical freshwater food webs by juvenile mullets: a case study in southern Brazil. Aquat Biol. 2014; 20(1):91-100.

Pace ML, Carpenter SR, Cole JJ, Coloso JJ, Kitchell JF, Hodgson JR, Middelburg JJ, Preston ND, Solomon CT, Weidel BC. Does terrestrial organic carbon subsidize the planktonic food web in a clear water lake? Limnol Oceanogr. 2007; 52(5):2177-89.

Pelz O, Cifuentes LA, Hammer BT, Kelley CA, Coffin RB. Tracing the assimilation of organic compounds using $\delta^{13} \mathrm{C}$ analysis of unique amino acids in the bacterial peptidoglycan cell wall. Microb Ecol. 1998; 25(3) 229-40.

Phillips DL, Gregg JW. Source partitioning using stable isotopes: coping with too many sources. Oecologia. 2003; 136(2):261-69.

Phillips DL, Inger R, Bearhop S, Jackson AL, Moore JW, Parnell AC, Semmens BX, Ward EJ. Best practices for use of stable isotope mixing models in food-web studies. Can J Zool. 2014; 92(10):823-35.

Pilati A. Stoichiometry and the relative importance of autochthonous and allochthonous food sources for a dominant detritivorous fish. [PhD Thesis]. Oxford, Ohio, USA: Miami University; 2007.

Reynolds CS. A changing paradigm of pelagic food webs. Int Rev Hydrobiol. 2008; 93(4-5):517-31.

Rodrigues LC, Train S, Bovo-Scomparin VM, Jati S. Interannual variability of phytoplankton in the main rivers of the Upper Paraná River floodplain, Brazil: influence of upstream reservoirs. Braz J Biol. 2009; 69(2):501-16.

Romagnolo MB, Souza MC. Análise florística e estrutural de florestas ripárias do alto rio Paraná, Taquaruçu, MS. Acta Bot Bras. 2000; 14(2):163-74.

Santana ARA, Benedito E, Ducatti C, Lansac-Tôha FA. Isotopic fractionation and trophic position of zooplankton species in the Upper Paraná River floodplain. Braz J Biol. 2011; 71(1):71-76.

Santana ARA, Lansac-Tôha FA, Benedito-Cecilio E. Variability of $\delta^{13} \mathrm{C}$ and $\delta^{15} \mathrm{~N}$ in three zooplankton species from the Upper Paraná River floodplain. Zoologia. 2009; 26(4):725-32.

Santana ARA, Werth M, Benedito-Cecilio E. Use of food resources by detritivorous fish in floodplains: a synthesis. Acta Biol Colomb. 2015; 20(1):5-14.

Smoot JC, Findlay RH. Caloric needs of detritivorous gizzard shad Dorosoma cepedianum are met with sediment bacterial and algal biomass. Aquat Biol. 2010a; 8(2):105-14.

Smoot JC, Findlay RH. Microbes as food for sediment-ingesting detritivores: low-density particles confer a nutritional advantage. Aquatic Microb Ecol. 2010b; 59(2):103-09. 
Solomon CT, Carpenter SR, Clayton MK, Cole JJ, Coloso JJ, Pace ML, Vander Zanden MJ, Weidel BC. Terrestrial, benthic, and pelagic resource use in lakes: results from a three isotope Bayesian mixing model. Ecology. 2011; 92(5):1115-25.

Solomon CT, Carpenter SR, Cole JJ, Pace ML. Support of benthic invertebrates by detrital resources and current autochthonous primary production: results from a whole-lake ${ }^{13} \mathrm{C}$ addition. Freshw Biol. 2008; 53(1):42-54.

Souza-Filho EE, Comunello E, Rocha PC. Flood Extension in the Baía-Curutuba-Ivinhema Complex of the Paraná river floodplain. In: Agostinho AA, Rodrigues L, Gomes LC, Thomaz SM, Miranda LE, editors. Structure and functioning of the Paraná River and its floodplain. Maringá: Eduem; 2004. p.19-24.

Stanford JA, Lorang MS, Hauer FR. The shifting habitat mosaic of river ecosystems. Verh Internat Verein Limnol. 2005; 29(1):123-36.

Stephens DW, Krebs JR. Foraging theory. New Jersey: Princeton University; 1986.

Torsvik SR, Sørheim R, Goksøyr J. Total bacterial diversity in soil and sediment communities - a review. J Ind Microbiol Biotechnol. 1996; 17(3-4):170-78.

Vance ED, Brookes PC, Jenkinson DS. An extraction method for measuring soil microbial biomass C. Soil Biol Biochem. 1987; 19(6):703-07.

Vanni MJ, Renwick WH, Bowling AM, Horgan MJ, Christian AD. Nutrient stoichiometry of linked catchment-lake systems along a gradient of land use. Freshw Biol. 2011; 56(5):791-811.

Wagener SM, Oswood MW, Shimel JP. River and soils: parallels in carbon and nutrient processing. BioScience. 1998; 48(2):104-08.

Werth M, Kuzyakov Y. Root-derived carbon in soil respiration and microbial biomass determined by ${ }^{14} \mathrm{C}$ and ${ }^{13} \mathrm{C}$. Soil Biol Biochem. 2008; 40(3):625-37.

Wetzel RG. Reservoir ecosystems: conclusions and speculations. In: Thornton KW, Kimmel BL, Payne FE, editors. Reservoir limnology: Ecological perspectives. New Jersey: John Wiley and Sons; 1990. p. 227-238.

Winemiller KO, Flecker AS, Hoeinghaus DJ. Patch dynamics and environmental heterogeneity in lotic ecosystems. J North Am Benthol Soc. 2010; 29(1):84-99.

Wu J, Joergensen RG, Pommerening B, Chaussod R, Brookes PC. Measurement of soil microbial biomass $C$ by fumigationextraction: an automated procedure. Soil Biol Biochem. 1990; 22(8):1167-69.

Yossa MI, Araujo-Lima CARM. Detritivory in two Amazonian fish species. J Fish Biol. 1998; 52(6):1141-53.

Zeug SC, Winemiller KO. Evidence supporting the importance of terrestrial carbon in a large-river food web. Ecology. 2008; 89(6):1733-43.

Submitted September 16, 2016 Accepted August 17, 2018 by David Hoeinghaus 